\title{
A Guide to Understanding and Combatting Digital Capitalism
}

\author{
Javier de Rivera \\ Universidad Complutense de Madrid, Spain. jigro@ucm.es, javierderivera.net
}

\begin{abstract}
This article offers a general description of digital capitalism, understood as a system in which social and economic dynamics revolve around digital corporations and their infrastructures. The aim of this analysis is to help develop strategies to counteract capitalism. It takes an historical perspective, considering capitalism as an evolving system driven by a continuous flight from the tendency of the rate of profit to fall. Fixed Capital and General Intellect are addressed as key analytical concepts for understanding the role of technology in capitalism, particularly in the digital era. Subjectivity formation is also a key element, as capitalism needs to progressively improve its strategies of ideological manipulation in order to survive. In the conclusion, I present five strategic principles to counteract digital capitalism. These strategies were developed in the Grupo de Estudios Críticos de Madrid (GEC-Madrid), an interdisciplinary group created in 2018 by the National Museum Reina Sofia (Spain) in order to coordinate the cycle "Six Contradictions and the End of the Present", a series of lectures and workshops with internationally recognized scholars, followed by research seminars to discuss their ideas.
\end{abstract}

Keywords: platform capitalism, digital domination, general Intellect, alternatives, autonomous spaces, collective thought.

Acknowledgement: This paper is an extended version of a short article published in Spanish for the journal Papeles de relaciones ecosociales y cambio social (2018a). Its content is in great part the result of my participation in the Grupo de Estudios de Críticos de Madrid and the cycle 'Six Contradictions and the End of the Present' directed by Carlos Prieto, at the Museo Reina Sofía in Spain. The present paper has also been significantly improved through the submission process, for which I have to thank the evaluators and the editorial team. I would also like to acknowledge Jed Rosenstein (jedrosenstein@gmail.com) for his careful grammar review.

\section{Introduction: Digital Capitalism}

The concept of digital capitalism was introduced in the late 1990s to emphasize the role of digital technologies in the success of economic globalization. Schiller (2000) describes it as a "new epoch" in which "cyberspace not only exemplifies but today actually shapes the greater political economy" (16) and "networks generalize the social and cultural range of the capitalist economy" (14). However, this interpretation is far from being consolidated and the term is frequently used in a generic sense, for example giving title to articles or monographs (Jimenez and Rendueles 2020; Fuchs and Mosco 2015), without their authors really delving into its meaning as a new social paradigm.

In Marxism: Key Ideas in Media \& Cultural studies, Fuchs (2020a) defines digital capitalism as one dimension of capitalism among others, namely "the part of capitalism that is organized around the production of digital commodities and digital products" (71). With this interpretation of the concept as a category of capitalism, the author discards the idea of a structural change associated with digitalization, pointing to the eco- 
nomic relevance of other sectors such as finance and real estate. From our perspective, the impact of digital companies goes beyond the commodities they produce or their market share, in the sense that they enable new regimes of accumulation and social control. Furthermore, digital technologies play a key role in the economy, providing the basic infrastructure for communication and organizational practices.

The definition of stages or phases in capitalism is always controversial. First, the interest in branding the 'actual spirit of the times' stimulates the proliferation of superficial descriptive names for capitalism (Cancela 2020). Secondly, the development of capitalism is multidimensional and continual, so each new layer of the system develops along (or over) others, progressively increasing complexity, making it difficult to define tipping points. Therefore, digital capitalism can be understood both and simultaneously as a layer or dimension of the capitalist system and as its new stage, since this layer assumes a leading role in the economy but does not modify the system's basic dynamics. In other words, "capitalist society remains the same at the most basic level by changing at upper levels of organization" (Fuchs 2020a, 71).

In this article we will argue in favor of the thesis that digital capitalism represents a new stage of capitalism because digital markets have renewed the strategies of capital reproduction, temporarily overcoming the tendency of the rate of profit to fall by strengthening the regulatory power of capital over society. In this case, digital platforms operate as key agents of capitalist development, not necessarily regarding the value of the assets they actually manage or the profits they make, but because of how they mobilize market forces, creating new habits and shaping a new type of society.

\section{Platforms in Digital Capitalism}

Platforms are responsible for the management of digital markets, which open new cycles of value extraction and capital accumulation. Their relevance in the new economy has led to the concept of "platform capitalism" (Srnicek 2016), very much related to what we are describing here, although we consider platforms as part of a larger socioeconomic order in which they assume a leading role, but in coordination with the wide range of institutions that take part in the digital economy. In this regard, the performance of platforms is deeply dependent on their relation to financial markets and government policy.

The importance of digital platforms is particularly obvious in the case of the five large corporations that are at the top of the rankings of market capitalization - Google, Apple, Facebook, Amazon and Microsoft, popularly known as GAFAM and considered an Internet oligopoly (Smyrnaios 2016). However, focusing on the particular practices of these companies does not permit us to grasp the underlying logic behind this form/stage of capitalism. What matters is that a new way of organizing the economy and generating revenue has been established and is having a deep impact on cultural and social dynamics. The aim of this article is to deepen our understanding of this logic in order to define strategies for resisting and counteracting the resulting concentration of power.

The main feature of digital platforms is their extraordinary scalability, that is, their ability to amplify the offer of a service without modifying the conditions of production. When traditional companies increase their production, they have to carry out organizational changes proportional to their external growth: hiring staff, acquiring premises and increasing management costs. In contrast, digital services can significantly increase their number of users with minimal impact upon the organization, aside from the necessary improvement of technical infrastructure (servers, bandwidth, etc.). Initially, the launch of a digital project requires a large capital investment, but once 
properly developed it can operate globally without increasing costs directly. In other words, when certain thresholds have been reached, billing possibilities grow exponentially while costs do so arithmetically. For this reason, digital companies can generate outstanding profits, with productivity ratios that easily exceed one million dollars per hired employee (Fu and Jones 2017).

The profitability of digital platforms make them a privileged investment vehicle for financial funds, eager to find new pools in which to fish for profits. There is, therefore, never a shortage of venture capital available to sponsor the development of new digital companies, and those that are consolidated can easily negotiate to attract new capital. Digital capitalism is the result of a structural alliance between financial and technological elites, in which the former have gradually lost their hegemony in favor of the latter, who affirm their dominant position. In other words, driven by the imperative to increase the profitability of their funds, the representatives of financial capital are forced to accept the position of power assumed by technology entrepreneurs (Surowiecki 2012; Fernholz 2014). In turn, successful digital platforms satisfy the funds' need for profit margins by making use of their unparalleled ability to organize and influence the activities of billions of users worldwide.

From a historical perspective, each new stage of capitalism has entailed an improvement in the dynamics of accumulation. The evolution of capitalism is driven by a flight forward to escape the tendency of the rate of profit to fall (Marx 1990/1967). In the nineteenth century, when profits from national markets began to dry up, industrial capitalism sought new markets, leading Western powers to intensify the violent conquest of other territories. Imperialism is the highest stage of capitalism (Lenin 1963/1917), because its systemic motivation is the constant search for profit, making expansionism a structural requirement (Arendt 1994/1968; Harvey 2003). At the end of the last century, when the cycle of economic growth slowed down, capitalism reinvented itself through financialization, a spatio-temporal fix (Harvey 2003, 87) that added a new layer of abstraction to the economy in order to continue the process of capital accumulation (Neal 1993; Storm 2018). Financial capitalism was accompanied by cultural and political changes, such as new levels of consumerism boosted by innovative marketing techniques and the the rise of neoliberal policies that flattened global thinking (Metcalf 2017). Today, as the ability of financial speculation to keep pace with the imperative of economic growth comes under scrutiny, capitalism is improving the efficiency of its systems of value-extraction through digital platforms and markets.

The present stage of capitalism has also been described by Italian postoperaist thinkers as "cognitive capitalism", which can be defined as the intertwining of a complex set of transformations, including financialization, the commodification of culture and digital technologies, all of which revolve around the centrality of knowledge and immaterial labor in the process of value extraction and capital accumulation (Boutang 2011). Our account of digital capitalism could be considered as the latest stage of cognitive capitalism, which comes after financialization began to reach its own limits - as made evident by the 2008 crisis - and new strategies for capital accumulation had to be deployed. Rushkoff (2016) describes the emergence of the digital economy, explaining that after the market has extended over all the physical terrain of the planet, the search for new horizons continues through the colonization of the human mind. To that end, digital platforms capture human attention with their infinite offer of content and interfaces designed to engage users with virtual updates and rewards (Busby 2018). Reed Hastings, founder of Netflix, explained the situation clearly at the Summit LA17: 
"Think about if you didn't watch Netflix last night: What did you do? There's such a broad range of things that you might do to relax and unwind, hang out, and connect-and we compete with all of that ... so we actually compete with sleep" (Raphael 2017, 10-11).

The attention being captured is not only valuable in terms of consumer expenditure of time and money, it is also an asset in terms of the opportunity it represents to promote values and ideas. In this sense, communication technologies long ago demonstrated their potential as thought technologies, designed to capture attention and manipulate desire (Wu 2016). Today their ability to structure public subjectivities has become the cornerstone of the economic and social system.

\section{Global Digital Domination}

The main digital corporations have managed to position themselves as natural monopolies, providing informational infrastructures that function as new public utilities (Rahman 2017). As a consequence, their applications are accepted as if they were a public service. Take Google as an example, its mail and storage systems are used by default by private and public institutions, such as universities, providing this corporation with the management of their data. Furthermore, this company is also behind the massive digitalization of books from public libraries (Coyle 2006), and their software is shamelessly installed by default in most of the cellphones that are sold today.

As the power of national states has eroded due to neoliberal policies, the public turns to giant digital corporations to satisfy its needs to organize and manage information (Vaidhyanathan 2011). Facebook/Instagram and Twitter capitalize on controlling the bulk of social communication on the Web. Their degree of social acceptance is such that their logos are included - for free - in the advertisements of consumer products, television programs and other promotional campaigns. Computers, cellphones and other devices are sold with default applications designed to massively collect data about their users. Billions of users around the world, whatever their status, accept situations in which they are intensely monitored by private companies as 'normal', be it for commercial purposes or on behalf of state surveillance agencies, as the Snowden (2019) revelations showed in 2013 (Greenwald 2015). Instead of leading to political change, the exposure of massive surveillance practices has led to behaviors of social adaptation and resignation, as found in several studies (Penney 2016; Mathews and Tucker 2017). Dencik and Cable (2017) describe this phenomenon as 'surveillance realism', updating Fisher's (2009) notion of "capitalist realism", and arguing that compliance with a system is based on the perception of its inevitability, regardless of the recognition of its flaws and injustices. In addition, the way in which the pervasive surveillance of digital capitalism compels every individual user to give away their personal information in exchange for access (Draper and Turow 2019), can be understood as collective behavior of learned helplessness (Seligman 1975). Society as a whole has given up protecting itself against the new forms of digital domination. Widespread submission to the power of digital corporations is commonly justified by presenting them as agents of progress. Furthermore, accepting their guardianship is often considered as the only way to enjoy the practical advantages of technology (Winner 2017). This ideology of progress has a deep neoliberal bias because it naturalizes the idea that the winners in the economic game can dictate the rules of that game, and takes for granted that major economic players are legitimate political actors (Foucault 2008). Nowadays, companies of all sectors and sizes compete to reach people via Facebook or to position themselves on the Google algorithm (Pasquinelly 2009), but 
no one is in a position to compete against these two corporations that have irrefutably managed to dominate the digital networks.

Monopoly is the natural aspiration of digital ventures, explains Peter Thiel (2014), one of the most prestigious investors in Silicon Valley. The key is for a company to achieve a competitive advantage that allows it to be the first to capitalize on a sufficiently large user base, such that the network effect - the added value of a network with many nodes - outgames any competitor. Getting Facebook to be profitable cost $\$ 1$ billion, invested between 2004 and 2009. Since then, annual revenues have multiplied the aggregate investment of those 5 years by 10 . Today, we might be able to build a platform with the same features for much less, but we would lack the 2 billion users and all the accumulated knowledge that makes Facebook the well-tuned advertising machine it currently is. In its beginnings, this platform made 1 dollar yearly per user, nowadays they extract up to 15 dollars per user (Facebook 2016; 2017; 2018).

In short, the secret of Facebook's profitability lies in two key assets: its database of users and the knowledge it has accumulated about those users. The development of advanced technologies for the massive exploitation of digital databases, commercially known as Big Data, provides the market intelligence to choose the appropriate message for a selected target in order to achieve the desired effect on their thinking and behavior (Couldy and Turow 2014; Bourreau, de Streel and Graef 2017). With these techniques, companies like Facebook are able to offer cheap and efficient advertising, not only optimizing the sales of all types of commercial products but also the promotion of lifestyles and political attitudes.

In this regard, the Cambridge Analytica leak demonstrated the acquiescence of Facebook in the development of a massive machinery of political suggestion run on misinformation (Cadwalldr and Graham-Harrison 2018). Inside this and other platforms, false political messages can be disseminated selectively, without leaving any public record and thereby evading accountability. Thus, the monopolistic position of dominant digital platforms, which have become the main means of social communication, creates the conditions of possibility for the establishment of a post-truth regime, in which the framework of social reality itself comes to be questioned (Coppins 2020). Overloaded with contradictory information, the general population loses interest in factbased political debate, allowing emotions to shape its thoughts and actions; those emotions, in turn, are easily manipulated by the suggestion machinery of social media. The surprising electoral victories of Brexit, Trump and Bolsonaro demonstrate the seriousness of this political drift towards digital totalitarianism.

\section{General Intellect and the Production Machinery}

Digital technologies have significantly amplified capital's ability to intervene in social life. The essential dynamic of capitalism is its capacity to transform life-time into alienated-time, in which social action is directed towards the reproductive interests of capital. Industrial capitalism transformed the work force into a commodity that could be appropriated by capital; in exchange for a wage, workers joined the productive machinery, becoming cogs in the process, subsuming their energy and knowledge within it.

Industrialization consists of systematizing production techniques, outsourcing them to machines that carry within themselves the technical knowledge previously possessed only by the artisan worker. In the process of building the machine, human labor and knowledge are fixed into an artifact. Then, whoever uses that machine amplifies the effect of their action because that operator is mobilizing the human potential embedded within the machine. Thus, industrialization represents a step forward towards 
material progress, an effective accumulation of technical knowledge that enables large projects to be carried out.

However, fixing a large amount of intellectual and physical capacity into a technical object facilitates that capacity becoming the "private property" of the capitalist, diminishing the leverage that embodied knowledge lends workers. In other words, while skilled workers always own their knowledge, which cannot be extracted from their bodies, the knowledge-made-object, or technological artifact, can be bought and privately owned. In this sense, Marx (1992/1882; 1994/1939) referred to technology as "fixed capital", that is, as means of production, the ownership of which defines power relations in capitalist society. So, although technological advances allow for improved production - and potentially improved quality of life - they also increase the possibilities of greater alienation, as they increase the ability of capital to appropriate human work, intensifying pre-existing relations of domination.

The Luddites understood this truth. Their attacks on machines were not based on traditionalist superstition, but on the organized defense of their communities against a technology that increased the power of capital over labor (Bindfield 2004). They understood that the problem was not the machine itself but rather the property regime that turned it against them. In short, technology becomes a tool of economic and political domination because it is privately owned. If technology were to be recognized as the result of collective work and knowledge, then its development would be considered a political issue that impacts society as a whole. In other words, technology is the result of social relations and, once fixed in machines, it shapes society by enabling new powers and abilities; therefore the question is: who gets to decide what technologies should be developed and how?

The Italian post-operaists evoke the notion of technology as a common good when they recuperate the concept of General Intellect, an abstraction of the collective knowledge expressed in the fusion of workers and machinery, from Marx (1939/1993). In line with the Marxist promise of proletarian emancipation, the post-operaists suggest that cognitive workers will find new ways of liberation in the technical appropriation of the productive process (Berardi 2001). However, as the digital machine grows, both material and ideological alienation increase and become more complex. It seems the success of cybernetics, the "science of control" (Winner 1977), has unbalanced the dialectic between work and capital in favor of the latter, enabling it to appropriate more of society's cognitive resources (Tiqqun 2020).

Throughout the 20th century, marketing and commercial advertising improved the means by which human desire could be ideologically alienated and reoriented towards consumption. "As soon as the degree of abundance attained in the production of goods demands an additional collaboration of the worker, he is suddenly considered 'in his leisure and humanity' and treated with solicitous courtesy, under the guise of consumer". This is how Guy Debord $(1994 / 1967,43)$ explains the role of the spectacular seduction that enlisted workers in the task of consuming commodity surpluses. Structurally, capital accumulation cannot continue without the circular process of production and consumption, which has to be funded by financialization and debt. Workers are invited to sell their labor in advance though loans, while nation-states sell their assets, including their workforce and their sovereignty, to international financial capital. In Debord's social critique, this ultimately leads to "the consummate denial of the human being" (1994/1967, 43). However, just when it seemed alienation could go no further, digital capitalism has managed to take it an additional step. Tiziana Terranova was the first to point out how digital technology companies generate spaces for spontaneous 
cooperation among users in order to appropriate the fruits of their collaboration, profiting off their free work through data and advertising (2000). Platforms operate like farmlands, environments designed to extract the maximum value from users, in the form of data and engagement. Users index their habits, tastes and interests, thus increasing the ability of capital to 'seduce' them through targeted advertising. Furthermore, social habits are manipulated according to the strategic needs of capital. Platforms are designed to transmit communicational values and principles that socialize users into a certain subjectivity (Gehl 2014). Features such as the "Like" button educate users into seeking positive feedback (Eranti and Lonkila 2016). Therefore, even when these platforms also enable authentic social collaboration and mobilization, they slowly work to gain influence over the population. Digital capitalism has progressively built a massive and complex system of social manipulation. In the long run, we, the users, become an asset to be monetized by selling access to our minds to commercial companies and political organizations.

\section{The New Digital Economy}

In the present state of digital capitalism, the appropriation of social collaboration by platforms has superseded the realm of digital interaction, aiming at substituting traditional exchange markets. Popularized under the guise of the 'sharing' or 'collaborative' economy (Botsman 2010; 2015), peer-to-peer digital markets offer new opportunities for successful ventures. The profitability of these platforms lies in their strategy of outsourcing production costs to users who, as "prosumers", take charge of providing and managing the entire supply of goods and services offered in the digital market. Platforms pay the fixed costs of maintaining the infrastructure, while obtaining a direct percentage of all the transactions made within their systems, building highly profitable economies of scale.

However, the greatest competitive advantage of the "collaborative economy" comes from how it circumvents the laws and taxes that regulate traditional markets. In other words, the true innovation of this model is the use of technology to mobilize the productive capacity of individual users, enabling them to carry out a commercial activity below the radar of market regulation (Morozov 2016). This strategy has also been possible thanks to the public relations discourses that have framed the phenomenon as a new era of consumption, based on "collaboration", in which individuals share resources to meet each other's material needs. This argument has been promoted through books, conferences and articles to influence public opinion and advocate legal permissiveness towards these practices (de Rivera and Gordo 2020).

Thus, the offer of tourist accommodation through Airbnb makes it possible to bypass the legislation that applies to hotels (taxation, security, licenses), systematizing a black market for holiday rental. Until the company was large enough to cause serious housing issues in major cities, no regulatory initiatives were taken and critical voices were not heard, and even now few regulatory initiatives are in place (Sherwood 2019).

The case of Uber is probably more glaring, given how the company sought to disguise the commercial transportation services offered by its platform as a peer-to-peer system that would connect passengers and drivers. In this case, the labor-based nature of the service made it all too evident that the company was trying to mobilize a fleet of "clandestine taxis". Nevertheless, it was only after taxi companies and unions filed lawsuits that regulatory measures were taken, forcing the company to recognize the commercial nature of its service (El País 2016). Even so, taxi drivers still accuse Uber of unfair competition as fewer regulations apply to the latter service, despite the fact that it is essentially a taxi service. 
Likewise the invasion of rental scooters and motorcycles on the streets of many major cities is another instance of the use of fixed capital to extract social value, this time by colonizing public space. Municipalities around the world are allowing this practice on the premise that these initiatives improve urban transportation. However these vehicles represent the materialization of digital capital in our cities, improving companies' ability to extract data and, in the long run aim at substituting public transportation. In addition, there are more than reasonable concerns about the sustainability of these rental models, because of how they are related to an overproduction of vehicles that end up underused, as has happened with large bike renting enterprises in China (Huang, 2018).

The inaction of public institutions when it comes to regulating these practices is a direct consequence of the neoliberal discourse and its reverence for capital reproduction. European Commission (2016) guidelines enthusiastically recommend that governments avoid over-regulating new digital trade initiatives, in hopes that these initiatives might stimulate the economy. Citizens in turn have been easily seduced by affordable consumption options as well as by the possibility of finding new means of income - something increasingly urgent in a context of widespread precariousness.

However, in the face of economic crisis, neoliberal recipes further aggravate the situation, putting more elaborate strategies of economic domination to work. Users who turn to these platforms hoping to reinvent themselves, become "entrepreneurs of themselves", developing a subjectivity primarily based on a cost-benefit rationale (Foucault 2008; Gil 2017). In this sense, the most egregious discursive contradiction of the "sharing economy" is how it describes its exchanges as more human, more social, somehow warmer, when, on the contrary, the "new economic era based on trust" promised by its advocates (Botsman 2015) leads to the introduction of complex regulatory systems based on "virtual reputation", which becomes a currency that commodifies friendliness. These mechanisms ensure the self-discipline of their users, who strive to "modulate" their behavior to improve their scores, as predicted by Deleuze in his description of the society of control (1992) governed though digital machines.

\section{Subjectivity and Discourse}

Advertising discourses often exploit the potential of the "double bind", the logical contradiction between what is said and what is done, in order to nullify a subject's analytical capacity (Bateson et al. 1956). The manipulation of desire towards illusion requires the semiotic structure of advertising to falsely conceal a contradiction. The most typical of these structures is the notion that individuals can differentiate themselves and express their individuality by acquiring mass-produced commodities. For commodities to appear capable of fulfilling this expectation they must be associated with unrealistic properties that offer shortcuts to the effortless attainment of goals, the immediate satisfaction of desires, or to the acquisition of the symbolic value enshrined in brands.

As big brands, digital corporations brilliantly use this resource in their marketing campaigns. In one Amazon ad, smiling boxes sing lullabies, although the firms (unseen) workers suffer from exploitative working conditions. Tinder ads speak of women's empowerment and self-assurance while promoting extreme individualism and objectification in human relationships. Uber ads emphasize inclusivity and work opportunities, while trashing workers' rights. In the spectacular language of advertising, the terms of reality are reversed. Capital is invested in the production of an inverted reality that consolidates social submission and alienation (Debord 1994/1967).

However, beyond advertising, neoliberal subjectivity is most effectively interiorized through practice. When users learn to take advantage of the functionalities of digital 
platforms to lend commercial value to their passions, skills or material assets, an alliance arises between their individual strategies of self promotion and the corporate interests of the platform. The competitiveness that classic neoliberal discourse promotes in the professional sphere enters into the private sphere, socializing users in the dynamics of selling their personal lives and maximizing their consumption opportunities. In their search for social success and positive feedback, users are driven to take an active role in the production of a "networked spectacle" (Della Ratta 2020) that fuels and legitimizes digital capitalism. Never mind that success is ultimately only available for a few - supposedly those who try hard enough - while most users struggle to attain popularity; nor does it matter that in the long run highly competitive dynamics weaken social bonds and cause social distress. In short, all these discourses of self-promotion - both explicitly advertised and implicitly embedded in the systems - end up strengthening the social acceptance of digital capitalism.

In this way, digital platforms perfect the capitalist technologies of the self for the development of subjectivities that are dependent on their structures. As explained by Bröckling (2015) - following Foucault - the paradox of the subject is such that the realization of his/her individuality is tied to his/her 'subjection' to a regime of power. This is what happens when users 'express themselves' in social media: they develop their own way of being, intertwining their lifestyles with the dynamics of digital capitalism. This paradox also affects the formation of critical discourses, which lose transformative potential when they become 'content' in social media, that is, commodities for the purposes of entertainment and self promotion. Discourses and practices, content and channel, intertwine in the process of shaping subjectivities that end up consolidating the power of capital over society.

\section{Building Spaces of Autonomy}

According to the philosophy of praxis, the purpose of theoretical analysis is to serve the development of political action, which in this case means finding ways to counteract digital capitalism. This is why the final section of this article will present five strategic principles to this end. They were developed over the course of several working sessions of the Grupo de Estudios Críticos de Madrid (GEC), an interdisciplinary group created to coordinate a series of activities within the cycle "Six Contradictions and the End of the Present" directed by Carlos Prieto and held at the Museo Nacional Centro de Arte Reina Sofia in 2018 (MNCARS 2018a; GEC 2018). The cycle consisted of six events with invited international scholars, each of whom gave a public lecture and a workshop for 30 to 40 people interested in his/her work. GEC coordinators facilitated these public events (lectures and workshops) and organized a series of seminars before and after the visit of each international scholar. The seminars were attended by the members of GEC, a stable group of 10-15 people with different backgrounds: scholars, activists and artists. The aim of the seminars was to delve into the guests' work, prepare the discussion for the workshop and draw conclusions from the experience.

The principles presented here were developed in the seminars accompanying the visits of Trebor Scholz and Tiziana Terranova in September 2018. In the preparatory session we discussed these scholars' work, drawing upon a selection of readings chosen in collaboration with them and published on the Museum's website as part of the cycle. After the guest lectures we met again to discuss and detail our conclusions. In these sessions 8-10 people participated, and the discussion was influenced by the previous seminars and events in the cycle, including the visits of Evegeny Morozov (March), Franco Berardi Bifo (April) and Keeanga-Yamahtta Taylor (June). After these 
sessions, the cycle continued with the visits of Paul Mason (December 2018) and Nancy Fraser (March 20191).

Morozov's analysis of algorithm sovereignty (2015) clearly illustrates the magnitude of the problem that digital capitalism represents, although the group did not find his proposals convincing because they depend on the action of governments that have already demonstrated a strong neoliberal bias (de Rivera 2018b). Bifo's sensibility touched us, making us aware that subjectivity, community, bonding and the liberation of desire have to be taken into consideration (de Rivera and Coral 2018). Taylor brought us back to the rough reality of everyday repression, especially as suffered by minorities, which is representative of the core of ignorance and hate driving social domination (MNCARS 2018b). Looking back, we can say the trajectory of shared learning experiences built a certain common theoretical background and a convergent perspective on praxis within the GEC.

Then, in the September sessions, Terranova's sharp updating of Marxist theory for the digital age in 'Free Labor' (2000) made a deep impact upon most members of the group, while her recent works, such as 'Red Stack Attack' (2014), encouraged us to think in ways that might counteract digital capitalism. In addition, Scholz's perspective on platform cooperativism (2016) highlighted the practicality of designing operative and realistic alternatives. While the limitations of cooperativism to counteract capitalism were quickly recognized by the group, the discussion led us to delve into ways of overcoming these limitations.

With all these influences present, we held a session dedicated to drafting analyses and solutions to the problems of digital capitalism. The strategic principles presented here were identified in that session and are documented in the proceedings as an epilogue entitled "Requirements for transformative cooperativism" (GEC 2018b). Framing the question in terms of cooperatives made us focus on practicality, leading us to five tangible requirements that are developed here as strategic principles applicable to any kind of initiative aimed at counteracting digital capitalism. In this sense, we did not opt to theorize about global alternatives, such as Post-capitalism (Mason 2015) or any of the possible forms of digital socialism (Fuchs 2020b). Instead, we focused on the shortterm aim of helping to build and strengthen autonomous spaces for collective action, what we consider a necessary step in the long road to superseding digital capitalism in favor of something better. Another agreement the group came to was that these initiatives, while waging transformative social dynamics, should function within a capitalist environment without being absorbed into its logic.

As noted by Vassilis Charitsis in his review of the present article before its publication, our approach resonates with those of John Holloway (2010) and Erik Wright (2010), in the sense that we all explore the possibilities of counteracting the power of capitalism in a context of uncertainty. According to Wright, "the unintended consequences of deliberate efforts at social change" $(2010,5)$ make it impracticable to develop a revolutionary master plan to overthrown capitalism. Instead, we need to use critical knowledge to promote an "incremental tinkering" of alternatives to exploitation, moving towards "a process of increasing social empowerment over state and economy." (2010, 6). For his part, Holloway (2010) assumes a similar position when he calls to "crack capitalism" by any possible means, intensifying the strength of alternatives

1 Her visit had to be postponed, and officially was not part of the cycle, but the GEC group still participated in coordinating the public events and celebrated a special presentation of the Feminist Manifest for the 99\% (Arruza, Bhattacharya and Frase 2019) in the occupied social center La Ingobernable (2019; GEC 2019). 
growing in the interstices of the system, such as small and local initiatives that could converge from multiple angles to create accumulative effects of social transformation.

The following proposal of five strategic principles shares a a similar motivation: to use the knowledge of how capitalism impacts our lives in order to develop ways of opening consistent cracks in its pervasive logic.

\subsection{Principle 1: The Political Turn}

Capitalism is characterized by a cleavage between the economic and political sphere, with the former ruling over the latter (Polanyi 2010; Gil 2014). Neoliberalism has intensified the process by establishing economic growth as the "permanent social consensus" (Foucault 1979) that guides political decision making, leading to national governments doing their best to remain in the good graces of major corporations, which are seen as strategic partners for economic development.

The political turn aims at reversing this process from the ground up by challenging the rule of economic and instrumental reason over subjective processes of decision making. This means recognizing the essence of decision making as political, in the sense that our decisions - in whatever sphere - only make sense in relation to the polis, that is, to the common space in which we exist and become who we are. This also implies considering how our actions affect others and how we are all connected through a web of interactions that produce and maintain the social order.

Weber (1978) pointed out there are two forms of rationality guiding social action: instrumental reason aimed at finding the best means to attain any given goal; and value-rationality, which is based on the values and principles that are meaningful to us. Hence, the political turn means emphasizing this second form of thinking in order to collectively identify the values that, according to our principles, should inform our "political will".

In practical terms, the political turn could begin by calling on public institutions to prioritize social needs over corporate interests or economic growth, which in the realm of digital capitalism would simply mean asking for equitable regulatory frameworks. However, the real transformative effect of this strategic principle comes when it permeates the internal structures of initiatives aimed at counteracting capitalism, so they can be based on strong political values. Furthermore, the political turn should become a major cultural value influencing decision-making even at the individual level, promoting the idea that daily actions have political meaning and relevance. Submission requires subjectivities that consider individual actions not to matter; revolutionary change comes from the opposite belief.

\subsection{Principle 2: The Discursive Battle for Subjectivity}

This principle represents the extension of the political turn into everyday life, in what has been also described as micropolitics (Guattari and Rolnik 2006), reflecting the premise that a fundamental battle against capitalism has to be waged on the terrain of subjectivity. It connects with the powerful idea that the personal is political (Hanish 1970), which arose within radical feminism, and teaches us that our personal issues are an expression of oppressive social relations. Therefore, changing the social order also implies changing our way of thinking, feeling and relating to each other.

The "politics of subjectivation" (Rolnik 2017) are the corner stone of how capitalism manages to shape our way of living to conform with the interests of capital accumulation. Counteracting them means releasing the power of desire captured by the commodity form and directing it towards community building and self-realization. This is a complex task to achieve from within a society subsumed by the logic of capital. It is an 
asymmetric confrontation in which critical thought needs to be nurtured long term in independent venues, while capital continues its mass production of cultural commodities impregnated by ideology (Debord 1967, 34.).

Traditionally, independent thought has been hosted in public institutions, such as universities or research centers, but the advance of neoliberalism has undermined support for such public institutions. For this reason we need to create new spaces for collective encounter and reflection in which greater (self-)understanding and awareness can be cultivated, favouring the dissemination of critical discourses. Producing and keeping alive non-capitalist (non-alienated) subjectivities also requires strengthening community bonds and networks of mutual care, because people need to feel the alternative to capitalism already exists in the hearts of their peers².

In this context, social media was praised in its beginnings for creating spaces of social dialogue and shared knowledge, but capitalist platforms ended up strengthening the machinery of manipulation. Therefore, we need to reduce the mediation of commercial platforms in our social relations and rely on other channels of communication, even if that means returning to emails and phone calls. However, digital media still offers opportunities for the creation of alternative venues for social discussion, anytime these resources can be used outside of the control of the corporations of digital capitalism.

\subsection{Principle 3: Technological Sovereignty and Ethics by Design}

Commercial platforms are successful because they address basic needs, although they also contribute to the living conditions that exacerbate those needs. For example, online dating sites address the need for emotional and sexual intimacy, while they actively promote the superficial, individualistic and competitive culture behind many emotional and relational problems. Dating sites are more about profiling users and training algorithms than about actually helping people to satisfy their emotional and sexual needs. Corporate platforms put their search for profit over their users' interests, so the latter are only satisfied to the extent that they are necessary for the former. Therefore, users' dependency on commercial technological solutions to satisfy basic needs leaves their subjectivity under the influence of digital corporations.

Technological sovereignty would mean that users would have some sort of say in the policies of the platform, or at least the assurance that it is not mainly run for the purposes of extracting value from them. For this reason, autonomous services sustained by micro-donations or user memberships are vital to counteract digital capitalism. Unless we manage to shift communication to alternative channels, digital corporations will continue to increase their ability to manipulate the population, whether directly though advertisement and disinformation or indirectly through the values embedded in their systems (Gehl 2014). We also need to guarantee that these alternative channels function under principles of transparency, privacy, security and social equity. Artifacts have politics which are inscribed in their design and manifested in their use (Winner 1986; Mumford 1967). In this sense, technological sovereignty is both an expression of the political turn and of the need to open free spaces for the formation of revolutionary subjectivities.

In the mean time, the power of digital capitalism should also be counteracted by all means possible, such as demanding digital policies that protect the rights of users and citizens. There is a legal and cultural battle for the definition of acceptable standards

2 In reference to the words of Durruti, reproduced in Preston (1984, 235): "We carry a new world in our heart" 
for technological development. If not for the resistance of the Free Software Movement, which emerged in the 1980s, the principles of code openness and modifiability would probably be utopian. In the same fashion, the current movement for "algorithm sovereignty" advocates for the use of transparent and participatory algorithms (Roio 2018), while making evident the abuse of power behind the proprietary algorithms applied by the corporations of digital capitalism.

\subsection{Principle 4: Collective Capital, Infrastructures and Organization}

One of the major benefits of digital technologies is they reduce the cost of communication, which makes it easer to take the step from political awareness to solidarity networks and then to social organizing. The radical-tech collectives from the 1990s that gave birth to Indymedia quickly took advantage of these possibilities by building international networks for social movements. Riseup (US) and Autistici (Italy) are initiatives from that time that are still functioning, providing technological services for activists under sustainable organizational and economic models. However, most alternative services became obsolete when large amounts of financial capital began to flow into the digital ventures that eventually took over the Internet with platforms designed to capture attention and manipulate desires in order to extract value from society. This is how the cycle of digital capitalism began.

To counteract this cycle and as a necessary step for the development of higher forms of social organizing it is necessary to find ways to channel labor and resources toward the construction of alternative digital infrastructures. We have already pointed out that the political revolution originally advocated by socialist thinkers seems improbable nowadays, therefore, counter-capitalist initiatives must be able to work within the rules of the capitalist economy while challenging it from within. This means they have to address the imperatives of growth and profit without being absorbed by them. In their initial phases, startups reinvest their profits in their "fixed capital" in order to scale up and increase their future profitability. Counter-capitalist initiatives should follow the same logic because the money to sustain large sovereign infrastructures can only be generated through economies of scale.

The challenge is to develop organizational models able to produce an effective collectivization of the means of production while competing in a capitalist environment. In practical terms, there is a need for profitable models that are not based on exploitative relationships, as well as for governing systems based on democratic or communal decision making. For such projects to succeed, the previous three strategic principles should already at work, creating a favorable sociocultural environment based on revolutionary values. Without a solid social base of sympathizers that might support counter-capitalist initiatives economically through memberships or consumption habits, it would not be possible to gather enough collective capital to ensure their sustainability. In other words, political awareness, critical thinking and solidarity networks are the preconditions for the foundation of any counter-capitalist initiative, which would then also need to channel sufficient labor and material resources to develop highly effective organizational structures.

\subsection{Principle 5: Investing in Social Relations}

Capital is a social relation between persons established by the instrumentality of things (Marx 1990/1867), that is, mediated by money and commodities. Therefore, the key to dismantling the power of capital is to diminish the role of the "instrumentality of things" in mediating social relations, re-establishing the basis of the latter on political principles 
and social values. We already discussed this necessity in our examination of the political turn, but now we need to examine how it might become operative on a large scale.

In his study of social differences, sociologist Pierre Bourdieu developed the theory of "the forms of capital" (1986), arguing that aside from "economic capital" - which remains the basic form of capital - there are other forms of accumulative power (capital), such as "cultural capital" and "social capital". The centrality of knowledge in the digital economy could be considered from the point of view of this theory as "cultural capital", but it is his concept of "social capital" that we are going to consider here. Although all capital is "social" in a general sense, Bourdieu defines social capital as "the aggregate of the actual or potential resources which are linked to possession of a durable network of more or less institutionalized relationships" $(1986,249)$. In common language we might say it is the opportunities we may obtain through our "friends", but the theory allows us to delve into the structural value of friendship and its importance in counteracting the alienating effects of capitalism.

Social capital accumulates through acquaintanceship and mutual recognition, growing significantly through long-term alliances. Therefore, it is a value created through the labor of interacting, collaborating or cooperating, especially when these interactions are maintained over time and/or systematically organized. In this sense, we can say that social capital emerges from the surplus value of interactions, that is, from the relationships that emerge when we interact or collaborate with other people. Digital platforms aim to appropriate this surplus value of collaboration, accumulating social capital in the form of "engaged users" whose data and attention they can monetize. This is why we need alternative digital venues where social collaboration can be liberated from this sort of exploitation.

However, this is not enough. The resources liberated from the cycles of capital accumulation have to be mobilized against capitalism, that is, reinvested to liberate further resources. The logic of capitalism assumes the accumulation of capital as an end in itself, with social relations as a means that serves that end. To counteract capitalism we have to follow the opposite logic, considering social relations as an end in themselves and economic resources as the means to create situations in which relations can flourish. This also means understanding that our existence only make sense in relation to each other, therefore, there is nothing more reasonable than systematically favoring social relations based on solidarity, equality and cooperation.

The concept of "social capital" helps us recognize social bonds as a form of capital - understood as an accumulated potentiality - that can be collectively managed and shared, building resilient communities that are able to support each other and mobilize large amounts of labor and resources when needed. This fifth strategic principle attempts to systematize the practice of mutual aid (Kropotkin 1902/2014) by framing it in resonance with the previous principles. In practical terms the application of this principle can be something as simple as investing in our communities without looking for any benefits other than improving social life itself, a necessary counter-capitalist move.

\section{Conclusion: The Interaction of the Five Principles}

The first principle indicates alternatives to capitalism are defined by their political orientation, that is, by their meaning and reasons for being. Economic competition is ultimately driven by the narcissistic desire to feel superior to others through access to material advantages and lavish spending. Counter-capitalist initiatives should be motivated by a non-competitive sense of life, in which individuals feel valued as part of a community, not in opposition to it. This communitarian subjectivity has to be nurtured over time, while resisting and fighting disinformation, ideological/hate speech and the 
manipulation of desire by capitalist media. This requires spheres where values and rules are not determined by capitalist interests, but collectively. Today, since digital interactions are a critical aspect of social life, it has become urgent to count on alternatives to capitalist platforms designed to extract value from users. The principle of technological sovereignty speaks to this need, inviting us to reflect on how roles and productive relations are organized to produce these digital environments. Then, there is the imperative of efficiency and economic sustainability to maintain and secure collective infrastructures.

In theory, all of these principles are positive as a foundation for counteracting digital capitalism, however, realizing them in practice might seem impossible in the current state of things. Then is when the relevance of the fifth principle comes in. Many counter-capitalist projects are likely to fail or stagnate, but their value should not be considered only in terms of their success or survival as organizations, but on how they enrich social relations, liberating "social capital" and disseminating revolutionary knowledge in order to nurture the birth of new initiatives that will continue developing the same principles, accumulating results and improving outcomes.

\section{References}

Arent, Hannah. 1994/1968. Imperialism. The Origins of Totalitarism. Part Two. New York: Hartcourt Brace.

Arruzza, Cinzia, Tithi Bhattacharya and Nancy Fraser. 2019. Feminism for the 99\%. A Manifesto. New York: Verso Books.

Bateson, Gregory, Don D. Jackson, Jay Haley and John Weakland. 1956. Toward a Theory of Schizophrenia. Behavioral Science 1 (4): 251-264.

Berardi, Franco (Bifo). 2001. La fabbrica dell'infelicita'. New economy e movimento del cognitariato. Rome: DeriveApprodi.

Binfield, Kevin. 2004. Writings of the Luddites. Baltimore, MD: The John Hopkins University Press.

Botsman, Rachel and Roo Rogers. 2010. What's Mine is Yours: The Rise of Collaborative Consumption. Nueva York, NY: Harper Collins.

Botsman, Rachel. 2015. Defining The Sharing Economy: What Is Collaborative Consumption-And What Isn't? Fast Company, May, 27. Accessed on March, 30, 2020.

https://www.fastcoexist.com/3046119/defining-the-sharing-economy-what-is-collaborativeconsumption-and-what-isnt

Bourdieu, Pierre. 1986. The Forms of Capital. In Handbook of Theory and Research for the Sociology of Education, edited by John G. Richardson, 241-258. Westport, Conn.: Greenwood Press.

Bourreau, Marc, Alexandre de Streel and Inge Graef. 2017. Big Data and Competition Policy: Market Power, Personalised Pricing and Advertising. Project Report. Centre on Regulation in Europe. Accessed on March 30, 2020. https://ssrn.com/abstract=2920301 or http://dx.doi.org/10.2139/ssrn.2920301

Bröckling, Ulrich. 2015. The Entrepreneurial Self. Fabricating a New Type of Subject. London: Sage.

Busby, Mattha. 2018. Social Media Copies Gambling Methods 'to Create Psychological Cravings'. The Guardian. May, 8. Accessed on March 30, 2020. https://www.theguardian.com/technology/2018/may/08/social-media-copies-gambling-methods-to-create-psychological-cravings

Cadwalldr, Carol and Emma Graham-Harrison. 2018. Revealed: 50 Million Facebook Profiles Harvested for Cambridge Analytica in Major Data Breach. The Guardian. Accessed on March 30, 2020. https://www.theguardian.com/news/2018/mar/17/cambridge-analyticafacebook-influence-us-election 
Cancela, Ekaitz. 2020. No hay alternativa al socialismo: los límites de la lucha de clases en el capitalismo digital Teknokultura. Revista de Cultura Digital y Movimientos Sociales 17 (2). https://doi.org/10.5209/tekn.70378

Coppins, McKay. 2020. The Billion-Dollar Disinformation Campaign to Reelect the President. The Atlantic. March Issue. Accessed on March 30, 2020. https://www.theatlantic.com/magazine/archive/2020/03/the-2020-disinformation-war/605530/

Couldry, Nick and Joseph Turow. 2014. Advertising, Big Data and the Clearance of the Public Fealm: Marketers' New Approaches to the Content Subsidy. International Journal of Communication 8: 1710-1726. Accessed on March 30, 2020. https://ijoc.org/index.php/ijoc/article/view/2166

Coyle, Karen. 2006. Mass Digitalization of Books. The Journal of Academic Librarianship 32 (6): 641-645. Accessed on March 30, 2020. https://doi.org/10.1016/j.acalib.2006.08.002

Debord, Guy. 1967/1994. The Society of the Spectacle. New York: Zone Books.

Deleuze, Giles. 1992. Postscript on the Societies of Control. October 59: 3-7. Accessed on March 30, 2020. http://jiangsu2018dukecourse.web.unc.edu/files/2018/07/Gilles-DeleuzePostscript-on-the-Societies-of-Control.pdf

Dencik, Lina and Jonathan Cable. 2017. The advent of surveillance realism: Public opinion and activist responses to the Snowden leaks. International Journal of Communication 11: 763-781

Draper, Nora A. and Joseph Turow. 2019. The Corporate Cultivation of Digital Resignation. New Media \& Society 21 (8): 1824-1839.

de Rivera, Javier. 2018a. Guía para entender y combatir el capitalismo digital. Papeles de relaciones ecosociales y cambio social 144: 79-89. Accessed on March, 30, 2020. http://javierderivera.net/wp-content/uploads/2019/08/ESP-entenderyCombatirCapitalismodigital-J.Rivera.pdf

de Rivera, Javier. 2018b. Digital Capitalism and Discontent. In Conversation with Evgeny Morozov.. Grupo de Estudios Críticos de Madrid. Accessed on March, 30, 2020. http://www.gec-madrid.org/2018/03/27/digital-capitalism-and-discontent-in-conversationwith-evgeny-morozov/

de Rivera, Javier and Coral Nieto. 2018. Subversión o Barbarie. Reflexiones sobre las jornadas con Franco Berardi, Bifo. Grupo de Estudios Críticos de Madrid. Accessed on March, 30, 2020. http://www.gec-madrid.org/2018/05/24/subversion-o-barbarie-reflexiones-aproposito-del-pensamiento-de-franco-berardi-bifo-parte-i/

de Rivera, Javier and Ángel Gordo. 2019. La oleada de la economía colaborativa y el estudio de nuevas formas de consumo. XIII Congreso Español de Sociología. Federación Española de Sociología.

El País. 2016. Uber regresa a Madrid con licencias de vehículos con conductor. Fran Serrano. El País. March, 26. Accessed on March 30, 2020. https://elpais.com/economia/2016/03/29/actualidad/1459249748 399031.html

Eranti, Veikko and Markku Lonkila. 2015. The Social Significance of the Facebook Like button. First Monday 20 (6). Accessed on March 30, 2020. https://doi.org/10.5210/fm.v20i6.5505

European Commission. 2016. A European Agenda for the Collaborative Economy. Accessed on March 30, 2020. http://ec.europa.eu/DocsRoom/documents/16881

Facebook Annual Reports. 2017. Accessed on March 30, 2020.

https://investor.fb.com/financials/?section=annualreports

Fernholz, Tim. 2014. How Mark Zuckerberg's control of Facebook Lets Him Print Money. Quartz. March, 27. Accessed on March 30, 2020. http://qz.com/192779/how-mark-zuckerbergs-control-of-facebook-lets-him-print-money/

Fisher, Mark. 2009. Capitalist Realism: Is There No Alternative? Hants, UK: Zero Books.

Foucault, Michel. 2008. The Birth of Biopolitics: Lectures at the Collège de France, 1978-79. New York: Palgrave Macmillan. 
Fu, Lisa and Stacy Jones. 2017. Chart: Tech Giants Earned More Than \$1 Million Per U.S. Worker In 2016. Forbes, June, 22. Accessed on March 30, 2020. https://fortune.com/2017/06/22/tech-automation-jobs/

Fuchs, Christian and Vincent Mosco, eds. 2020. Marx in the Age of Digital Capitalism. Leiden: Brill.

Fuchs, Christian. 2020a. Marxism: Karl Marx's Fifteen Key Concepts for Cultural and Communication Studies. New York: Routledge.

Fuchs, Christian. 2020b. Communicative Socialism/Digital Socialism. tripleC-Cognition, Communication, Co-operation: Open Access Journal for a Global Sustainable Information Society 18 (1): 1-31. Accessed on March 30, 2020. https://doi.org/10.31269/triplec.v18i1.1144

Huang, Frankie, 2018. The Rise and Fall of China's Cycling Empires. Foreign Policy, 31. December. Accessed on March 30, 2020. https://foreignpolicy.com/2018/12/31/a-billionbicyclists-can-be-wrong-china-business-bikeshare/

GEC. 2018a. Presentación. Grupo de Estudios Críticos de Madrid. Accessed on March 30, 2020. http://www.gec-madrid.org/presentacion-grupo-de-estudios-criticos/

GEC. 2018b. Analysis and search for solutions on digital/platform capitalism. Grupo de Estudios Críticos de Madrid. Accessed on March 30, 2020. http://www.gec-madrid.org/wpcontent/uploads/2018/09/Notes-on-Terranova-Scholz-seminar.pdf

GEC. 2019. Nancy Fraser: Capitalismo, derechos y luchas feministas. Grupo de Estudios Críticos de Madrid. Accessed on March 30, 2020. http://www.gec-madrid.org/2019/03/07/nancy-fraser-capitalismo-derechos-y-luchas-feministas/

Gehl, Robert. 2014. Reverse Engineering Social Media. Software, Culture and Political Economy in New Media Capitalism. Philadelphia, PA: Temple University Press.

Gil, Javier. 2015. "Karl Polanyi. Los límites del mercado: reflexiones sobre economía, antropología y democracia" Encrucijadas. Revista Crítica de Ciencias Sociales 7: 181-187

Gil, Javier. 2017. Economias colaborativas y crisis del capitalismo: Un análisis a través de la prosumición. In Ciberpolítica: gobierno abierto, redes, deliberación, democracia, edited by Ramón Cotarelo and Javier Gil, 167-188. Madrid: Instituto Nacional de Administración Pública.

Greenwald, Glen. 2015. No Place to Hide: Edward Snowden, the NSA, and the U.S. Surveillance State. New York: Penguin.

Guattari, Felix and Suely Rolnik, 2006. Micropolíticas. Cartografías del deseo. Madrid: Traficantes de sueños.

Harvey, David. 2003. The New Imperalism. Oxford: Oxford University Press.

Hanish, Caron, 1970. The Personal is Political. In Firestone and Anne Koedt (eds), Notes from the Second Year: Women's Liberation. New York: Radical Feminism. Accessed on March 30, 2020. http://www.carolhanisch.org/CHwritings/PIP.html

Holloway, John. 2010. Crack Capitalism. London: Pluto Press

Jiménez, Aitor and César Rendueles. 2020. Capitalismo digital: fragilidad social, explotación y solucionismo tecnológico. Teknokultura. Revista de Cultura Digital y Movimientos Sociales, 17(2). https://doi.org/10.5209/tekn.70378

Kropotkin, Pietr. 1902/2014. Mutual Aid: A Factor in Evolution. CreateSpace Independent Publishing Platform.

La Ingobernable, 2019. Encuentro: Manifiesto de un feminismo para el 99\%. Accessed on March 30, 2020. https://ingobernable.net/2019/03/13/encuentro-manifiesto-de-un-feminismo-para-el-99/

Lenin, Vladimir. 1963/1917. Imperialism, the Highest Stage of Capitalism. In Lenin's Selected Works, Volume One. Moscow: Progress Publishers.

Marthews, Alex and Catherine E. Tucker. 2017. Government Surveillance and Internet Search Behavior (February 17, 2017). SSRN. Accesed on October, 29. http://dx.doi.org/10.2139/ssrn.2412564 
Marx, Karl. 1990/1867. Capital: A Critique of Political Economy: Volume One. London: Penguin.

Marx, Karl. 1992/1885. Capital: A Critique of Political Economy: Volume Two. London: Penguin.

Marx, Karl. 1993/1939. Grundrisse: Foundations of the Critique of Political Economy. London: Penguin.

Mason, Paul. 2015. PostCapitalism: A Guide to Our Future. London: Allen Lane

Metcalf, Stephen. 2017. Neoliberalism: the idea that swallowed the world. The Guardian, August, 18. Accessed on March, 30, 2020. https://www.theguardian.com/news/2017/aug/18/neoliberalism-the-idea-that-changed-the-world

MNCARS. 2018a. Six Contradictions and the End of the Present. Museo Nacional Centro de Arte Reina. Accessed on March, 30, 2020. https://www.museoreinasofia.es/en/activities/six-contradictions-and-end-present

MNCARS. 2018b. Raciality and Care in the Dispute Over Other Lives. With KeeangaYamahtta Taylor y Yayo Herrero. Museo Nacional Centro de Arte Reina. Accessed on March 30, 2020. https://www.museoreinasofia.es/en/activities/six-contradictions-and-endpresent/yamahtta-herrero

Morozov, Evgeny. 2015. Socialize the Data Centers! New Left Review 91: 45-66. Accessed on March, 30, 2020. https://newleftreview.org/issues/ll91/articles/evgeny-morozov-socialize-the-data-centres.pdf

Morozov, Evgeny. 2016. Cheap cab ride? You must have missed Uber's true cost. The Guardian, Janury, 31. Accessed on March, 30, 2020.

https://www.theguardian.com/commentisfree/2016/jan/31/cheap-cab-ride-uber-true-costgoogle-wealth-taxation

Mumford, Lexis. 1967. Technics and Human Development. The Myth of the Machine. Volume One. San Diego, CA: Harcourt Brace Jovanovich

Neal, Larry. 1993. The rise of financial capitalism: International capital markets in the age of reason. Cambridge: Cambridge University Press.

Pasquinelli, Matteo. 2009. Google's PageRank Algorithm: A Diagram of Cognitive Capitalism and the Rentier of the Common Intellect. In Deep Search: The Politics of Search Beyond Google, edited by Konrad Becker and Felix Stalder, 152-162. Innsbruck: Studien Verlag.

Penney, Jonathon. 2016. Chilling Effects: Online Surveillance and Wikipedia Use. Berkeley Technology Law Journal 31 (1), 117-182.

Polanyi, Karl. 2010. The Limits of the Market. Oxford, UK: Polity Press.

Preston, Paul. 1984. Revolution and War in Spain, 1931-1939. York: Methuen Publishing

Rahman, K. Sabeel. 2017. The New Utilities: Private Power, social Infrastructure, and the Revival of the Public Utility Concept. Cardozo Law Review, 39: 1621-1689.

Raphael, Rina. 2017. Netflix CEO Reed Hastings: Sleep Is Our Competition. Fast Company. June, 11. Accessed on March, 30, 2020. https://www.fastcompany.com/40491939/netflixceo-reed-hastings-sleep-is-our-competition

Roio, Denis. 2018. Algorithmic Sovereignty. Doctorate Thesis. University of Plymouth. http://hdl.handle.net/10026.1/11101

Rolnik, Suely. 2017. The Spheres of Insurrection: Suggestions for Combating the Pimping of Life. E-flux journal 86. https://www.e-flux.com/journal/86/163107/the-spheres-of-insurrection-suggestions-for-combating-the-pimping-of-life/

Rushkoff, Douglas. 2016. Throwing Rocks at the Google Bus: How Growth Became the Enemy of Prosperity. New York, NY: Penguin.

Schiller, Daniel. 2000. Digital Capitalism: Networking the Global Market System. Cambridge, MA: MIT Press.

Scholz, Trebor. 2016. Platform Cooperativism: Challenging the Corporate Sharing Economy. New York, NY: Rosa Luxemburg Stiftung.

Seligman, Martin. 1975. Helplessness: On Depression, Development, and Death. San Francisco, CA: W.H. Freeman. 
Sherwood, Harriet. 2019. How Airbnb Took Over the World. The Guardian. May, 5. Accessed on March, 30, 2020. https://www.theguardian.com/technology/2019/may/05/airbnb-homelessness-renting-housing-accommodation-social-policy-cities-travel-leisure

Smyrnaios, Nikos. 2016. L'effet GAFAM: stratégies et logiques de l'oligopole de l'internet. Communication \& langages 188 (2): 61-83. https://doi.org/10.4074/S0336150016012047

Snowden, Edward. 2019. Permanent Record. New York: Metropolitan Books

Srnicek, Nick. 2016. Platform Capitalism. Cambridge: Polity Press.

Storm, Servaas. 2018. Financialization and Economic Development: A Debate on the Social Efficiency of Modern Finance. Development and Change 49 (2): 302-329. https://doi.org/10.1111/dech.12385

Surowieki, James. 2012. Unequal Shares. The Financial Page, The New Yorker. May, 28. Accessed on March, 30, 2020. http://www.newyorker.com/magazine/2012/05/28/unequalshares

Terranova, Tiziana. 2000. Free Labor: Producing Culture for the Digital Economy. Social Text 18 (2): 33-58. https://doi.org/10.1215/01642472-18-2 63-33

Terranova, Tiziana, 2014. Red Stack Attack! Algorithms, Capital and the Automation of the Common. In \#Accelerate. The Accelerationist Reader, edited by Robin Mackay and Armen Avanessian. Leipzig: Merve Verlag.

Tiqqun. 2020. The Cybernetic Hypothesis. Cambridge, MA: MIT Press.

Thiel, Peter. 2014. From Zero to One. Zero to One: Notes on Startups, or How to Build the Future. New York, NY: Crownbusiness.

Trebor, Scholz. 2016. Platform Cooperativism. Challenging the Corporate Sharing Economy. New York: Rosa Luxemburg Stiftung. Accessed on March, 30, 2020. http://www.rosaluxnyc.org/wp-content/files $\mathrm{mf} / \mathrm{scholz}$ platformcoop 5.9.2016.pdf

Vaidhyanathan, Siva. 2011. The Googlization of Everything (And Why We Should Worry). Berkeley, CA: University of California Press.

Winner, Langdon. 1977. Autonomous Technology. Technics-out-of-Control as a Theme in Political Though. Cambridge, MA: MIT Press.

Winner, Langdon, 1986. The Whale and the Reactor. A Search for Limits in an Age of High Technology. Chicago, IL: The University of Chicago Press.

Winner, Langdon. 2017. The Cult of Innovation: Its Colorful Myths and Rituals. On politics, technology and arts. June, 12. Accessed on March, 30, 2020. https://www.langdonwinner.com/other-writings/2017/6/12/the-cult-of-innovation-its-colorful-myths-and-rituals

Wright, Erik O. 2010. Envisioning Real Utopias. London: Verso

Wu, Tim. 2017. The Attention Merchants: The Epic Scramble to Get Inside Our Heads. New York: Atlantic Books.

\section{About the Author}

Javier de Rivera

Member of Research Group Cibersomosaguas, Cultura Digital y Movimientos Sociales at Universidad Complutense de Madrid. Editorial board member at Teknokultura Journal. PhD Thesis on The Sociology of Digital Institutions: a case study on the 'Collaborative Economy'. 